\title{
An Analysis of Illicit Drug Use and Motor Vehicle Fatalities Using Contiguous State-Level Data
}

\author{
by Andrew M. Welki and Thomas J. Zlatoper
}

This paper analyzes the influence of illicit drug use on highway fatal outcomes by estimating regression models using data for the 48 contiguous U.S. states for the years 2009 and 2010. The models include a representative, but not exhaustive, collection of roadway fatality determinants. The impact of illicit drug usage on the motor vehicle death rate differs across age groups. There are statistically significant life-taking effects from marijuana use by the very youngest drivers. Comparable effects from the usage of cocaine and nonmedical pain relievers occur among older drivers. Negatively associated with the highway death rate and statistically significant are real per capita income and seat belt use. Statistically significant positive relationships with the rate are found for the ratio of rural to urban driving, temperature, speed limit, the percentage of older drivers, and cell phone usage. The paper provides information to policy makers at a time when state-level drug laws are changing rapidly. Evidence reported here on how drug use affects highway fatal outcomes is relevant to that discussion.

\section{INTRODUCTION}

Driving under the influence of psychoactive (mind-altering) drugs is unsafe, placing at risk both motor vehicle occupants and others using highways (National Institute on Drug Abuse 2014). In 2009, one third of fatally injured U.S. drivers tested positive for drugs other than alcohol (National Highway Traffic Safety Administration [NHTSA] 2010a). This suggests there is a serious drugged driving problem nationally. Despite that reality, the U.S. lags other countries in research and enforcement related to this issue (DuPont 2011).

This paper investigates the influence of illicit drug use on U.S. highway safety. Specifically, it estimates the relationship between such usage and motor vehicle fatalities, while controlling for the impact of a representative collection of highway death determinants. A unique contribution is the utilization of state-level data, including information on drug use broken down by drug types and user age groups.

This study has the following format: The first section summarizes research findings for the U.S. on drug use by drivers and the impact of such usage on highway crash risk. A model that explains motor vehicle fatalities is specified in the second section. The paper's third section describes the data set used in the analysis, with regression estimates of the model reported and discussed in the fourth section. The final section summarizes the paper's findings.

\section{DRUGGED DRIVING IN U.S.}

The 2007 National Roadside Survey (NRS) provided the first estimates of drug-involved driving for the U.S. (Lacey et al. 2009). The data collection involved randomly stopping drivers at 300 locations, primarily at night on Fridays and Saturdays but also during the daytime on Fridays. Breath, oral fluid, and blood specimens were collected and tested for alcohol as well as three broad categories of drugs: illegal, prescription, and over-the-counter. Using a similar data collection methodology, the 2013-2014 NRS was the second U.S. survey that measured drug-involved driving (Kelly-Baker et al. 2016). 
Berning, Compton and Wochinger (2015) reported the following findings from the 2007 NRS and the 2013-2014 NRS on drug use by U.S. drivers: In 2013-2014, the extent of usage of any illegal drug was lower during weekday daytime (12.1\%) than during weekend nighttime $(15.2 \%)$; but usage of only medications (prescriptions and over-the counter) was higher during weekday daytime $(10.3 \%)$ than during weekend nighttime $(7.3 \%)$. During weekend nighttime, prevalence of any illegal drug increased from $12.4 \%$ in 2007 to $15.1 \%$ in 2013-2014, and prevalence of only medications grew from $3.9 \%$ in 2007 to $4.9 \%$ in 2013-2014. THC (delta 9 tetrahydrocannabinol), the psychoactive substance in marijuana, was the drug with the greatest growth in weekend nighttime prevalence-from $8.6 \%$ in 2007 to $12.6 \%$ in $2013-2014$.

Utilizing data from both the 2007 NRS and the Fatality Analysis Reporting System (FARS), Li, Brady, and Chen (2013) conducted a case-control study of driver drug use and fatal crash risk, including the impact of a drug-alcohol interaction. Their findings indicated that driver fatal crash risk increases (in ascending order) with the use of marijuana, narcotics, stimulants, and depressants. Additionally, results suggested that combining drugs and alcohol especially heightens the risk.

From persons hospitalized in California between 1990 and 2005, Callaghan and others (2013) constructed groups consisting of patients diagnosed with the following drug use disorders: methamphetamine, alcohol, opioids, cannabis, cocaine, or multiple drugs. Following the cohorts for several years, the researchers calculated standardized mortality rates (adjusted for age, sex, and race) for motor vehicle accident (MVA) deaths to compare to the general population of California. For every cohort, the standardized fatality ratios were elevated, implying higher MVA death risk for individuals with drug use disorders. Standardized ratios were similar for females and males.

Like Li, Brady, and Chen (2013), Romano and others (2014) used data from both the 2007 NRS and FARS to conduct a case-control analysis of fatal crash risk. They estimated logistic regressions that accounted for five predictors - gender, age, race/ethnicity, alcohol use, and drug use. Drug usage was found to increase the likelihood of fatal injury for both sober and drinking drivers. However, when drug use was divided into marijuana and other drugs, only the latter had a significant impact on fatal crash risk. Interaction between drugs and alcohol was not found to affect the risk.

Rudisill and others (2014) conducted a trend analysis using FARS data to identify changes in drug use patterns among drivers killed in U.S. motor vehicle crashes. Using a random effects model, they calculated prevalence rates and prevalence ratios comparing the patterns in 2009-2010 to those in 1999-2000. Their results indicated that usage of prescription drugs (e.g., narcotics and depressants) in general and cannabinoids has grown, while cocaine use apparently has diminished. The authors concluded that drug use among fatally injured drivers has increased and that a shift may have occurred, changing from illegal to prescription drugs.

Lacey and others (2016) conducted a case-control analysis of the influence on crash risk of driver use of drugs and alcohol. They utilized crash data from Virginia Beach, Virginia, over a 20-month period ending in 2012. Unlike the aforementioned case-control studies (Li, Brady, and Chen 2013; Romano et al. 2014) that focused on fatal crashes, Lacey and others (2016) considered fatal, injury, and property-damage crashes, although most in the data set were property-damage only. When not adjusting for other factors, marijuana use was found to increase crash risk; but after statistically controlling for age, gender, race/ethnicity, and alcohol use, neither marijuana nor any of the other over-the-counter, prescription and illegal drugs considered increased risk. Findings indicated that, adjusting for other factors, alcohol use increased crash risk, and there was no interactive effect between alcohol and drugs.

\section{MODEL}

The model used here explicitly includes five categories of explanatory factors: economic conditions, locational factors, weather conditions, regulations, and driver characteristics. ${ }^{1}$ Its general form is the following: 
(1) DEATHRT $=\mathrm{f}($ INCOME, RURURB, TEMP, PRECIP, SPEEDLIM, YOUNG, OLD, SBELTUSE, CELLPHN, ALCOHOL, DRUGUSE)

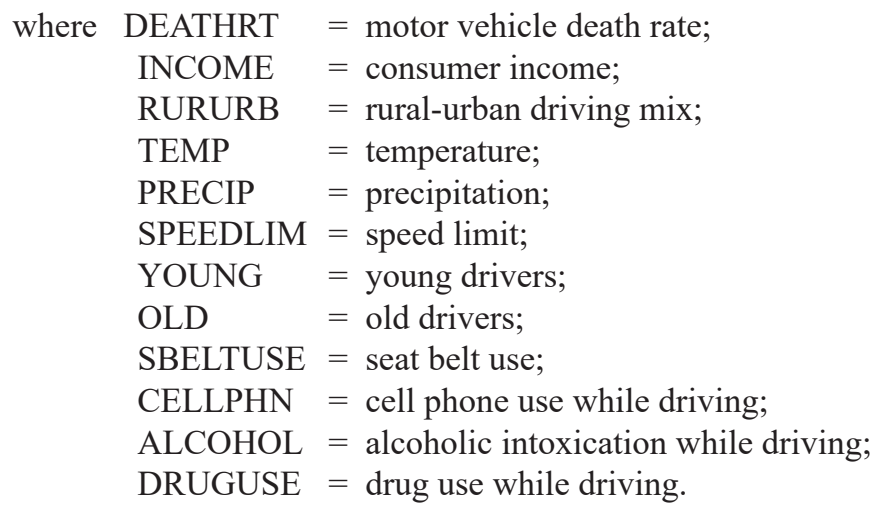

An explanation of the expected relationship between each explanatory factor and the death rate is below.

Income captures the prevailing economic conditions. Its impact on highway fatalities is uncertain a priori. Higher income should increase the demand for safety and driving intensity, assuming both are normal goods. ${ }^{2}$ Peltzman (1975) conjectures that the direction of the relationship between income and deaths is unclear due to these offsetting considerations. Loeb, Talley, and Zlatoper (1994, pp. 18-19) report that time-series studies provide evidence that supports a positive relationship, while cross-sectional and pooled analyses indicate a negative association.

Travel speeds are generally higher during rural, as opposed to urban, driving; and emergency medical treatment is typically more available in urban settings. As a result, the chance of death is likely greater when an accident occurs in a rural location. Loeb, Talley, and Zlatoper (1994, pp. 32) cite time-series and cross-sectional studies providing statistically significant evidence of inverse associations between motor vehicle fatality measures and the proportion of total travel occurring on urban highways. Given these findings, the locational measure employed here - the ratio of rural to urban travel - is anticipated to be positively related to the death rate.

The prevailing weather affects driving conditions. Loeb, Talley, and Zlatoper (1994, p. 34) report, based on cross-sectional analyses, that temperature and precipitation have statistically significant positive and negative associations, respectively, with highway fatality measures. Consistent with these results, the same associations are expected in this study.

This analysis controls for one driving regulation, the speed limit. Loeb, Talley, and Zlatoper (1994, p. 67) cite statistically significant findings, from time-series studies, that the speed limit is directly related to U.S. highway fatality rates and state-level driver injury rates. A similar positive relationship is hypothesized in this analysis.

Age is one of the five driver characteristics accounted for here. Younger motorists have less experience and are more inclined to take risks, while older drivers are subject to deterioration in physical factors (e.g., eyesight and reflexes) that can influence driving safety. Consequently, younger and older drivers may be more susceptible to motor vehicle accidents and deaths. However, Loeb, Talley, and Zlatoper (1994, pp. 24-25) report that the results in statistical studies examining the relationships between these two age groups and death measures are mixed. Given this inconclusive evidence, the anticipated relationship between the youngest and oldest age driving groups and highway fatality measures is uncertain a priori.

Another driver characteristic addressed is seat belt use. According to NHTSA (2001, Exhibit 6) estimates, the manual lap-shoulder belt is highly effective in saving the lives of car drivers. The 
National Center for Statistics and Analysis (2015) calculates that seat belt usage in passenger vehicles saved almost 13,000 lives in 2014. In contrast, Garbacz (1990) finds that seat belt use has no statistically significant effect on total, or driver, or overall occupant deaths. Further, it has a lifetaking impact on non-occupants and passengers. Given this mixed evidence, the expected relationship between highway fatality rates and seat belt use is uncertain a priori.

Drivers' use of cell phones is controlled for in this study. Cell phone usage can be life-taking when it distracts drivers, leading to fatal accidents. Alternatively, it can save lives by increasing the likelihood of quick assistance when an accident occurs. Using U.S. time-series data, Loeb, Clarke, and Anderson (2009) estimate highway fatality models that allow for a nonlinear cell phone effect. They find statistically significant evidence that the impact of mobile phones is nonmonotonic and depends on the volume of phone usage. As the volume increases, the effect is first net life-taking, then net life-saving, and lastly life-taking. Given the high volume of cell usage during the analysis period, cell phones are hypothesized to have a net life-taking influence on highways.

Alcohol usage is an additional driver characteristic analyzed. Conventional wisdom suggests intoxicated drivers are more likely to be involved in fatal crashes. Loeb, Talley, and Zlatoper (1994, pp. 20-21) share research evidence of a significant direct relationship between alcohol consumption and motor vehicle death measures in the U.S. The same association is anticipated in this study.

Drug use is the driver characteristic of particular interest in this study. As reported earlier, Li, Brady, and Chen (2013) find that fatal crash risk increases with such usage across a variety of drugs. The same relationship is expected here.

\section{DATA}

Annual data for the 48 contiguous U.S. states in the years 2009 and 2010 are utilized in this study. The dependent variable DEATHRT is measured using highway deaths per billion vehicle-miles. The source for the death and vehicle-miles figures is the Federal Highway Administration (FHWA) (various years).

The independent variable INCOME (real per capita disposable income, in dollars) is based on total nominal disposable income values from the Bureau of Economic Analysis (2011), population figures from the U.S. Census Bureau (2011 and 2014), and values of the Consumer Price Index for all urban consumers (base period: 1982-84) [Bureau of Labor Statistics (2014)]. FHWA (various years) is the data source for the explanatory variable RURURB (rural vehicle-miles divided by urban vehicle-miles). Weather variable information-TEMP (annual mean temperature, in degrees Fahrenheit) and PRECIP (annual precipitation, in inches)-comes from the National Climate Data Center (2011). The Ohio Insurance Institute (2015) supplies the information for SPEEDLIM (maximum rural interstate speed, in miles per hour) for the 48 states.

FHWA (various years) is the data source for the age-related driver characteristics, YOUNG (percentage of licensed drivers aged 24 years or younger) and OLD (percentage of licensed drivers aged 65 years or older). Information on SBELTUSE (seat belt use rate) for 2009 and 2010 comes from NHTSA (2010b) and NHTSA (2011), respectively. Figures used to calculate CELLPHN (per capita mobile telephone subscriptions) are from the Federal Communications Commission (2013) and the U.S. Census Bureau (2011 and 2014). ${ }^{3}$ Values for ALCOHOL (per capita apparent alcohol consumption, in gallons) for 2009 come from the National Institute on Alcohol Abuse and Alcoholism (NIAAA) (2011) and for 2010 come from NIAAA (2014). ${ }^{4}$

Data to capture drug use while driving come from the Substance Abuse and Mental Health Services Administration (2012). ${ }^{5}$ This information is provided for all ages combined (age group $12+)$ as well as for the following age subgroups (12-17, 18-25, and 26 and over) For all ages combined, three alternate sets of measures approximate drug usage in this study ${ }^{6}$ : (1) IDRUSPMO12+ (illicit drug use in the past month, percentage of age group $12+)^{7}$; (2) MARIJPMO12+ (marijuana use in the past month, percentage of age group 12+), and IDROMPMO12+ (illicit drug use other 
than marijuana in the past month, percentage of age group $12+)^{8}$; (3) MARIJPYR12+ (marijuana use in the past year, percentage of age group 12+), COCAIPYR12+ (cocaine use in the past year, percentage of age group 12+), and NMPRPYR12+ (nonmedical use of pain relievers in the past year, percentage of age group 12+). These three alternate sets of drug use measures are also broken down by the age subgroups. For example, IDRUSPMO1217 is illicit drug use in the past month as a percentage of the 12-17 age group. Table 1 provides summary statistics on all the variables used in the model estimations.

\section{ESTIMATION RESULTS}

The variables below ALCOHOL in Table 1 identify some patterns, across age categories, of drug usage. Across the three drug categories (marijuana, cocaine, and nonmedical use of pain relievers), the highest reported use is in the 18-25 age group. Alternatively, the group 26 years or older identifies with the lowest use, except for cocaine, for which its reported use rate (1.414\%) is slightly higher than that of the 12-17 age group (1.029\%). Further, usage rates for marijuana are higher in the last year than in the last month. Additionally, in the past year, marijuana use is highest among all age groups followed in descending order by nonmedical use of pain relievers and cocaine usage. The most noteworthy observation is that the 18-25 age group, young drivers who likely have the least driving experience to begin with (a risk factor for accidents), reports the highest use of illicit drugs. All of this may reflect an age group with a high degree of risky behavior.

Tables 2 and 3 each contain the regression estimation results for three different models with pooled data for two years. A Chow test confirmed that the data could be pooled. ${ }^{9}$ All models have linear functional forms and the same dependent variable, DEATHRT. Additionally, all models use exactly the same set of non-drug-related explanatory variables. Models 1, 2, and 3 differ based upon the degree of disaggregation in drug types and age groups.

The estimation results in Table 2 are based on drug usage variables aggregated across age groups, all persons 12 years of age or older. Distinctions are made between time periods of last reported usage, within last month or within last year. Table 3 results involve estimations utilizing the same drug categories with a set of disaggregated age categories. Those age groups are 12 to 17,18 to 25 , and 26 years or older. Based on R2 statistics, all of the models in Tables 2 and 3 explain more than three-quarters of the variation in DEATHRT.

The results for the non-drug related independent variables do not change with the level of aggregation for the drug variables. Consequently, these results are reported without identifying the specific model.

INCOME is statistically significant and negatively related to DEATHRT in all six models. ${ }^{10}$ These results suggest that better economic conditions increase the demand for safety, perhaps reflecting a higher opportunity cost of an accident and fewer fataly results. This finding is consistent with previous ones based upon pooled cross-section, time-series data.

Where (the location) a person drives influences DEATHRT. All six models reveal statistically significant evidence that as the ratio of rural to urban driving increases, so does the fatality rate. Rural driving conditions may differ in a number of ways: roads may be less congested, permitting higher speeds; road conditions may differ with respect to road surface and lighting; and rural settings may offer fewer nearby medical options in the event of an accident.

Higher temperatures and presumed better driving conditions are positively related to highway fatalities. Temperature may influence the driver's level of attention and visibility (sunlight) as well as vehicle speed. The result is significant across all six models. Precipitation, however, has a statistically insignificant impact on the death rate.

Faster speeds make roads less safe and increase the number of fatalities. Across all six models, SPEEDLIM reveals the anticipated positive sign and is statistically significant. 
Table 1: Summary Statistics of Variables

\begin{tabular}{|c|c|c|c|c|}
\hline Variable & Minimum & Maximum & Mean & $\begin{array}{c}\text { Standard } \\
\text { Deviation }\end{array}$ \\
\hline DEATHRT & 5.776 & 20.071 & 11.948 & 3.204 \\
\hline INCOME & $13,222.20$ & $22,391.75$ & $16,404.16$ & $2,121.19$ \\
\hline RURURB & 0.082 & 3.113 & 0.938 & 0.773 \\
\hline TEMP & 38.300 & 71.100 & 52.384 & 7.526 \\
\hline PRECIP & 7.690 & 75.050 & 38.684 & 15.565 \\
\hline SPEEDLIM & 65.000 & 75.000 & 69.610 & 3.929 \\
\hline YOUNG & 10.091 & 21.623 & 13.311 & 1.950 \\
\hline OLD & 9.883 & 20.451 & 16.292 & 1.819 \\
\hline SBELTUSE & 67.600 & 98.000 & 84.930 & 7.331 \\
\hline CELLPHN & 0.745 & 1.006 & 0.877 & 0.054 \\
\hline ALCOHOL & 1.330 & 4.440 & 2.387 & 0.483 \\
\hline IDRUSPMO12+ & 5.290 & 13.730 & 8.579 & 1.976 \\
\hline IDRUSPMO1217 & 6.890 & 13.170 & 9.941 & 1.468 \\
\hline IDRUSPMO1825 & 11.980 & 35.090 & 21.213 & 4.845 \\
\hline IDRUSPMO26+ & 3.400 & 10.750 & 6.243 & 1.707 \\
\hline MARIJPMO12+ & 3.110 & 11.570 & 6.615 & 1.831 \\
\hline MARIJPMO1217 & 3.680 & 11.510 & 7.209 & 1.551 \\
\hline MARIJPMO1825 & 7.740 & 32.010 & 18.115 & 4.845 \\
\hline MARIJPMO26+ & 1.900 & 8.860 & 4.574 & 1.483 \\
\hline IDROMPMO12+ & 2.010 & 5.510 & 3.603 & 0.650 \\
\hline IDROMPMO1217 & 3.560 & 5.640 & 4.505 & 0.474 \\
\hline IDROMPMO1825 & 4.980 & 12.730 & 8.425 & 1.660 \\
\hline IDROMPMO26+ & 1.240 & 4.350 & 2.661 & 0.601 \\
\hline MARIJPYR12+ & 6.940 & 16.990 & 11.105 & 2.345 \\
\hline MARIJPYR1217 & 9.270 & 19.530 & 13.622 & 2.423 \\
\hline MARIJPYR1825 & 17.700 & 46.350 & 30.112 & 6.304 \\
\hline MARIJPYR26+ & 3.700 & 12.540 & 7.527 & 1.866 \\
\hline COCAIPYR12+ & 0.970 & 3.890 & 1.894 & 0.576 \\
\hline COCAIPYR1217 & 0.610 & 1.500 & 1.029 & 0.174 \\
\hline COCAIPYR1825 & 2.610 & 10.170 & 5.330 & 1.715 \\
\hline COCAIPYR26+ & 0.580 & 3.170 & 1.414 & 0.494 \\
\hline NMPRPYR12+ & 3.570 & 8.140 & 5.022 & 0.857 \\
\hline NMPRPYR1217 & 4.580 & 9.320 & 6.719 & 0.944 \\
\hline NMPRPYR1825 & 8.480 & 17.940 & 12.339 & 1.946 \\
\hline NMPRPYR26+ & 2.190 & 6.200 & 3.552 & 0.767 \\
\hline
\end{tabular}


Table 2: U.S. State-Level Regression Estimates of Motor Vehicle Deaths per Vehicle-Mile, 2009-2010, Using Illicit Drug Use Data Aggregated Across Age Groups

\begin{tabular}{|c|c|c|c|c|}
\hline \multicolumn{5}{|c|}{ ( $\mathrm{t}$ statistic in parentheses beneath each coefficient) } \\
\hline \multirow{2}{*}{$\begin{array}{l}\text { Independent } \\
\text { Variable }\end{array}$} & \multirow{2}{*}{$\begin{array}{l}\text { Expected } \\
\text { Sign }\end{array}$} & \multicolumn{3}{|c|}{ Dependent Variable: DEATHRT } \\
\hline & & Model 1 & Model 2 & Model 3 \\
\hline \multirow[t]{2}{*}{ Intercept } & $?$ & -6.577 & $-12.609 b$ & $-20.332 b b$ \\
\hline & & $(-0.850)$ & $(-1.726)$ & $(-2.753)$ \\
\hline \multirow[t]{2}{*}{ INCOME } & $?$ & $-5.36 \mathrm{E}-04 \mathrm{bb}$ & $-3.98 \mathrm{E}-04 \mathrm{bb}$ & $-3.34 \mathrm{E}-04 \mathrm{bb}$ \\
\hline & & $(-4.443)$ & $(-3.417)$ & $(-2.778)$ \\
\hline \multirow[t]{2}{*}{ RURURB } & + & $1.986 \mathrm{aa}$ & $2.485 \mathrm{aa}$ & $2.597 \mathrm{aa}$ \\
\hline & & $(6.305)$ & $(7.801)$ & $(8.560)$ \\
\hline \multirow[t]{2}{*}{ TEMP } & + & $0.181 \mathrm{aa}$ & $0.142 \mathrm{aa}$ & $0.151 \mathrm{aa}$ \\
\hline & & $(5.167)$ & $(4.200)$ & $(4.844)$ \\
\hline \multirow[t]{2}{*}{ PRECIP } & - & -0.004 & 0.010 & 0.009 \\
\hline & & $(-0.200)$ & $(0.541)$ & $(0.510)$ \\
\hline \multirow[t]{2}{*}{ SPEEDLIM } & + & $0.179 \mathrm{aa}$ & $0.184 \mathrm{aa}$ & $0.172 \mathrm{aa}$ \\
\hline & & $(2.440)$ & $(2.730)$ & $(2.687)$ \\
\hline \multirow[t]{2}{*}{ YOUNG } & $?$ & -0.136 & -0.160 & -0.055 \\
\hline & & $(-1.133)$ & $(-1.449)$ & $(-0.510)$ \\
\hline \multirow[t]{2}{*}{ OLD } & $?$ & $0.350 \mathrm{bb}$ & $0.297 \mathrm{bb}$ & $0.391 \mathrm{bb}$ \\
\hline & & $(3.189)$ & $(2.892)$ & $(3.975)$ \\
\hline \multirow[t]{2}{*}{ SBELTUSE } & $?$ & $-0.077 b b$ & $-0.054 b b$ & -0.038 \\
\hline & & $(-2.869$ & $(-2.130)$ & $(-1.554)$ \\
\hline \multirow[t]{2}{*}{ CELLPHN } & + & $8.622 \mathrm{aa}$ & $9.955 \mathrm{aa}$ & $13.935 \mathrm{aa}$ \\
\hline & & $(2.021)$ & $(2.509)$ & $(3.566)$ \\
\hline \multirow[t]{2}{*}{ ALCOHOL } & + & 0.330 & 0.491 & 0.178 \\
\hline & & $(0.763)$ & $(1.212)$ & $0.460)$ \\
\hline \multirow[t]{2}{*}{ IDRUSPMO12+ } & + & -0.232 & & \\
\hline & & $(-2.049)$ & & \\
\hline \multirow[t]{2}{*}{ MARIJPMO12+ } & + & & -0.661 & \\
\hline & & & $(-4.417)$ & \\
\hline \multirow[t]{2}{*}{ IDROMPMO12+ } & + & & $1.254 \mathrm{aa}$ & \\
\hline & & & (3.338) & \\
\hline \multirow[t]{2}{*}{ MARIJPYR12+ } & + & & & -0.639 \\
\hline & & & & $(-5.598)$ \\
\hline \multirow[t]{2}{*}{ COCAIPYR12+ } & + & & & $1.483 \mathrm{aa}$ \\
\hline & & & & (3.473) \\
\hline \multirow[t]{2}{*}{ NMPRPYR12+ } & + & & & 0.861 aa \\
\hline & & & & $(3.450)$ \\
\hline $\mathrm{N}$ & & 96 & 96 & 96 \\
\hline $\mathrm{R}^{2}$ & & 0.767 & 0.803 & 0.827 \\
\hline Adjusted $\mathrm{R}^{2}$ & & 0.736 & 0.775 & 0.800 \\
\hline
\end{tabular}


Table 3: U.S. State-Level Regression Estimates of Motor Vehicle Deaths per Vehicle-Mile, 2009-2010, Using Illicit Drug Use Data Disaggregated by Age Groups

\begin{tabular}{|c|c|c|c|c|}
\hline \multicolumn{5}{|c|}{ ( $\mathrm{t}$ statistic in parentheses beneath each coefficient) } \\
\hline \multirow[b]{2}{*}{ Independent Variable } & \multirow{2}{*}{$\begin{array}{l}\text { Expected } \\
\text { Sign }\end{array}$} & \multicolumn{3}{|c|}{ Dependent Variable: DEATHRT } \\
\hline & & Model 1 & Model 2 & Model 3 \\
\hline \multirow[t]{2}{*}{ Intercept } & $?$ & -6.510 & -9.027 & -14.138 \\
\hline & & $(-0.784)$ & $(-1.109)$ & $(-1.610)$ \\
\hline \multirow[t]{2}{*}{ INCOME } & $?$ & $-5.29 \mathrm{E}-04 \mathrm{bb}$ & $-4.31 \mathrm{E}-04 \mathrm{bb}$ & $-2.85 \mathrm{E}-04 \mathrm{~b}$ \\
\hline & & $(-3.980)$ & $(-3.335)$ & $(-1.877)$ \\
\hline \multirow[t]{2}{*}{ RURURB } & + & 2.004aa & 2.606aa & $3.127 \mathrm{aa}$ \\
\hline & & $(6.196)$ & $(8.006)$ & $(9.086)$ \\
\hline \multirow[t]{2}{*}{ TEMP } & + & 0.178 aa & $0.119 \mathrm{aa}$ & 0.108 aa \\
\hline & & $(4.980)$ & $(3.393)$ & $(3.108)$ \\
\hline \multirow[t]{2}{*}{ PRECIP } & - & 0.001 & 0.019 & 0.021 \\
\hline & & $(0.053)$ & $(1.011)$ & $(1.025)$ \\
\hline \multirow[t]{2}{*}{ SPEEDLIM } & + & $0.173 \mathrm{aa}$ & $0.184 a a$ & $0.142 \mathrm{aa}$ \\
\hline & & $(2.189)$ & (2.489) & $(1.978)$ \\
\hline \multirow[t]{2}{*}{ YOUNG } & $?$ & -0.143 & -0.131 & -0.034 \\
\hline & & $(-1.159)$ & $(-1.158)$ & $(-0.313)$ \\
\hline \multirow[t]{2}{*}{ OLD } & $?$ & $0.351 \mathrm{bb}$ & $0.241 \mathrm{bb}$ & $0.361 \mathrm{bb}$ \\
\hline & & $(3.159)$ & $(2.284)$ & $(3.747)$ \\
\hline \multirow[t]{2}{*}{ SBELTUSE } & $?$ & $-0.079 b b$ & $-0.059 \mathrm{bb}$ & $-0.047 b$ \\
\hline & & $(-2.865)$ & $(-2.323)$ & $(-1.941)$ \\
\hline \multirow[t]{2}{*}{ CELLPHN } & + & $8.643 \mathrm{aa}$ & 8.833 aа & 11.090aa \\
\hline & & (1.992) & $(2.203)$ & $(2.502)$ \\
\hline \multirow[t]{2}{*}{ ALCOHOL } & + & 0.317 & 0.370 & -0.086 \\
\hline & & $(0.688)$ & $(0.890)$ & $(-0.216)$ \\
\hline \multirow[t]{2}{*}{ IDRUSPMO1825 } & + & 0.096 & & \\
\hline & & $(0.395)$ & & \\
\hline \multirow[t]{2}{*}{ IDRUSPMO1825 } & + & -0.081 & & \\
\hline & & $(-0.623)$ & & \\
\hline \multirow[t]{2}{*}{ IDRUSPMO26+ } & + & -0.130 & & \\
\hline & & $(-0.403)$ & & \\
\hline \multirow[t]{2}{*}{ MARIJPMO1217 } & + & & 0.135 & \\
\hline & & & $(0.505)$ & \\
\hline \multirow[t]{2}{*}{ MARIJPMO1825 } & + & & -0.016 & \\
\hline & & & $(-0.112)$ & \\
\hline \multirow[t]{2}{*}{ MARIJPMO26+ } & + & & -0.768 & \\
\hline & & & $(-2.326)$ & \\
\hline \multirow[t]{2}{*}{ IDROMPMO1217 } & + & & -0.052 & \\
\hline & & & $(-0.106)$ & \\
\hline
\end{tabular}


Table 3 (continued)

\begin{tabular}{|c|c|c|c|c|}
\hline \multirow[b]{2}{*}{ Independent Variable } & \multirow{2}{*}{$\begin{array}{l}\text { Expected } \\
\text { Sign }\end{array}$} & \multicolumn{3}{|c|}{ Dependent Variable: DEATHRT } \\
\hline & & Model 1 & Model 2 & Model 3 \\
\hline \multirow[t]{2}{*}{ IDROMPMO1825 } & + & & -0.267 & \\
\hline & & & $(-1.348)$ & \\
\hline \multirow[t]{2}{*}{ IDROMPMO26+ } & + & & $2.008 \mathrm{aa}$ & \\
\hline & & & $(3.594)$ & \\
\hline \multirow{2}{*}{ MARIJPYR1217 } & + & & & $0.434 \mathrm{aa}$ \\
\hline & & & & $(2.200)$ \\
\hline \multirow[t]{2}{*}{ MARIJPYR1825 } & + & & & -0.280 \\
\hline & & & & $(-2.515)$ \\
\hline \multirow[t]{2}{*}{ MARIJPYR26+ } & + & & & -0.379 \\
\hline & & & & $(-1.368)$ \\
\hline \multirow[t]{2}{*}{ COCAIPYR1217 } & + & & & 1.520 \\
\hline & & & & $(0.969)$ \\
\hline \multirow[t]{2}{*}{ COCAIPYR1825 } & + & & & -0.546 \\
\hline & & & & $(-1.622)$ \\
\hline \multirow[t]{2}{*}{ COCAIPYR26+ } & + & & & $2.807 \mathrm{aa}$ \\
\hline & & & & $(3.689)$ \\
\hline \multirow[t]{2}{*}{ NMPRPYR1217 } & + & & & -0.525 \\
\hline & & & & $(-1.536)$ \\
\hline \multirow[t]{2}{*}{ NMPRPYR1825 } & + & & & 0.262 \\
\hline & & & & $(1.262)$ \\
\hline \multirow[t]{2}{*}{ NMPRPYR26+ } & + & & & $0.960 \mathrm{a}$ \\
\hline & & & & $(1.508)$ \\
\hline & & & & \\
\hline $\mathrm{N}$ & & 96 & 96 & 96 \\
\hline $\mathrm{R} 2$ & & 0.767 & 0.817 & 0.852 \\
\hline Adjusted R2 & & 0.730 & 0.780 & 0.815 \\
\hline
\end{tabular}

${ }^{\mathrm{a}}$ significant at .10 level (one-tail test)

${ }^{\text {aa }}$ significant at .05 level (one-tail test)

$\mathrm{b}$ significant at .10 level (two-tail test)

${ }^{\mathrm{bb}}$ significant at .05 level (two-tail test) 
The age of the driving population is related to the death rate. There is strong evidence that the percentage of older drivers has a statistically significant and positive relationship with highway fatalities. Slower reflexes and deteriorating eyesight, among other reasons, may be factors. Conversely, the size of the pool of younger drivers is not linearly related to DEATHRT. In all six models, the coefficient for YOUNG is negative, yet in no case is the estimate statistically significant.

In this analysis, previous research findings by NHTSA are corroborated. Seat belt use has a lifesaving effect. Across all six models, the SBELTUSE coefficients are negative, and in only one case is the coefficient not statistically significant.

Cell phone usage, in this analysis, contributes to less safe driving conditions. CELLPHN's coefficient is always positive and statistically significant. The life-taking effect of a cell phone may result from driver distractions during calls, as well as physical challenges to make and answer calls. Evidently, the possible life-saving impact of the cell phone (faster response times) is not strong in this data set. The models included here assumed a linear effect of cell phone use on DEATHRT.

A large body of previous research supports the negative consequences of alcohol consumption on highway safety. In all but one model, Model 3 of Table 3, the positive coefficients are consistent with expectations. Higher levels of alcohol use are associated with higher motor vehicle death rates. None of the six models includes evidence of a statistically significant relationship. While the negative sign for ALCOHOL in Model 3 runs counter to conventional wisdom that greater alcohol consumption is associated with more fatalities, the estimated coefficient is not statistically significant.

Table 2 presents the results of the age aggregated drug use models. The models include drug usage in the past month and the past year. In Model 1, the anticipated positive sign for the coefficient of IDRUSPM012+ does not occur. Aggregate illicit drug use in the past month by individuals 12 or older does not increase the highway death rate.

When illicit drug use is disaggregated by drug type in Table 2, differences in road safety appear. Models 2 and 3 reveal illicit drugs other than marijuana increase highway fatalities for users within both the past month and the last year. Statistically significant positive relationships exist for the variables IDROMPMO12+, COCAIPYR12+, and NMPRPYR12+. In Table 2 models, marijuana use does not make roads less safe, as all variables accounting for marijuana have negative coefficients with $t$ statistics that are large in absolute value.

Models in Table 3 include variables to disaggregate age (12-17, 18-25, and 26+) and drug use type (marijuana, cocaine, and nonmedical use of pain relievers). In most cases, illicit drug use by the youngest drivers increases highway fatalities. Four of the six variables with the suffix 1217 reveal positive relationships. Of these, only marijuana is statistically significant in Model 3, the model with the most disaggregated groups. Evidently, the combination of the most inexperienced drivers and the age group most likely to be exploring drug use increases the motor vehicle fatality rate.

Only one of the six variables with the suffix 1825 (NMPRPYR1825 in Model 3) has a positive estimated coefficient. This implies that nonmedical use of pain relievers by those aged 18 to 25 is directly associated with the motor vehicle fatality rate, although the finding is not statistically significant. Young professionals may be making prudent decisions (e.g., utilizing designated drivers) about operating vehicles under the influence of drugs.

Three of the drug use variables with the suffix $26+$ have statistically significant positive estimated coefficients: IDROMPMO26+ in Model 2 and both COCAIPYR26+ and NMPRPYR26+ in Model 3. These results indicate that the motor vehicle death rate is directly linked to usage of cocaine and nonmedical pain relievers by individuals 26 and over. Apparently, these two drugs adversely affect the driving ability of older motorists.

A noteworthy finding of this study is that the impact on highway safety of drug use varies by drug type and age group. A statistically significant life-taking effect is found for marijuana usage by those aged 12-17 and for consumption of cocaine and nonmedical pain relievers by those aged 26 and over. 


\section{SUMMARY}

This paper is an effort to better understand the factors that influence motor vehicle deaths across U.S. states. Its contribution is adding illicit drug usage to a set of factors that explain deaths per vehicle-mile. Six models using estimated annual data for two years (2009 and 2010) for U.S. states, provide results generally consistent with previous findings.

Estimation results pertaining to the influences of several explanatory factors are robust across the models that include them. Negatively related to the fatality rate and statistically significant are real per capita income and seat belt use. Statistically significant positive associations with the highway death rate are found for the ratio of rural to urban driving, temperature, speed limit, percentage of older drivers, and cell phone usage.

One set of regression estimations are based on drug usage variables aggregated across age groups, all persons 12 years of age or older. These estimates reveal that use of both cocaine and nonmedical pain relievers increases highway fatalities. Counter to expectations, marijuana use does not make roads less safe as all variables accounting for marijuana have negative coefficients with $t$ statistics that are large in absolute value.

A second set of regression estimations employs drug usage variables disaggregated by age group (12-17 years, 18-25 years, and 26 years and over). These estimates reveal that the effect of illicit drug usage on motor vehicle deaths differs across age groups. Marijuana use among those aged 12-17 has a life-taking impact. In the age group 26 years old and over there is a different pattern in that use of both cocaine and nonmedical pain relievers contributes to an increase in highway fatalities.

The results of this research bring certain areas to the attention of policy makers and lawmakers. One area to consider is the information sharing boundary between the medical community, as a drug prescribing group, and the law enforcement group. There is increasing activity at the state level on the issue of liberalizing marijuana use, primarily for medical purposes. ${ }^{11}$ Given the findings reported here, proposed legislation should include deliberation about the different impacts on highway safety of such use across age groups. In particular, for young patients on a medical marijuana treatment program, it may be appropriate to consider an alternative minimum age for driving privileges. Further, the law enforcement community can work with the medical community to develop guidelines for vehicle operation while using medical marijuana. This issue becomes further complicated as individual states make decisions about medical marijuana and drivers cross state lines in their travels.

Greater emphasis can be placed on impaired driving while broadening the classification of such driving. Just as prescription drugs are monitored for overdoses and addictions, inappropriate use of prescription drugs has highway safety implications. This problem can be expected to increase with an aging driving population and a more widespread use of prescriptions for all types of medical conditions. The highway safety issues further intensify because of the consumption of cocaine and nonmedical pain relievers by older drivers.

While devices currently exist to detect alcohol levels during a traffic stop, police officers have no corresponding protocol for other substances that may cause driver impairment. Field tests represent the primary impairment detection strategy. Consequently, law enforcement officials may be making decisions with limited information. Greater research efforts to develop drug detection counterparts to the breathalyzer would help law enforcement professionals. Policy makers play a role, as they should decide how to balance patient privacy rights against a common good of highway safety. 


\section{Acknowledgements}

An earlier version of this paper was presented at the Eastern Economic Association Meetings in New York, New York, on February 28, 2015. The authors thank Dr. Michael W. Babcock, CoGeneral Editor, and two anonymous referees for several helpful suggestions and assume responsibility for any remaining errors.

\section{Endnotes}

1. Loeb, Talley, and Zlatoper (1994) summarize results of several empirical studies of highway death determinants until that point in time. Blattenberger, Fowles and Loeb (2013) summarize research that is more recent.

2. Peltzman (1975, p. 681) uses "driving intensity" to refer to greater "speed, thrills, etc.," that drivers gain by giving up some safety.

3. Data on cell phone use while driving are unavailable at the state level for 2009 and 2010 . Therefore, information on this activity for the population in general is utilized in this analysis. The assumption is made here that the behavior of drivers with regard to this activity is highly correlated with that in the general population.

4. Data on alcoholic intoxication while driving are unavailable at the state level for 2009 and 2010. Therefore, information on this activity for the population in general is utilized in this analysis. The assumption is made here that the behavior of drivers with regards to this activity is highly correlated with that in the general population.

5. Values used for 2009 are 2008-2009 estimates, and values utilized for 2010 are 2009-2010 estimates.

6. Data on drug use while driving are unavailable at the state level for 2009 and 2010. Therefore, information on this activity for the population in general is utilized in this analysis. The assumption is made here that the behavior of drivers with regard to this activity is highly correlated with that in the general population.

7. Illicit drugs include marijuana/hashish, cocaine (including crack), heroin, hallucinogens, inhalants, or prescription-type psychotherapeutics used nonmedically.

8. Illicit drugs other than marijuana include cocaine (including crack), heroin, hallucinogens, inhalants, or prescription-type psychotherapeutics used nonmedically.

9. A Chow test can determine whether a structural change in the relationship between the highway death rate and the explanatory variables occurred between 2009 and 2010. This test was conducted for each model. The results confirmed that the data for the two years could be pooled. See Gujarati and Porter (2009, pp. 254-259) for a discussion of the Chow test.

10. In this paper "statistically significant" refers to significance at a level of .10 or less.

11. According to ProCon.org (2015), during the years 2009 and 2010, marijuana was legal for medical purposes for at least a portion of the time in 15 states. 


\section{References}

Berning, A., R. Compton, and K. Wochinger. "Results of the 2013-2014 National Roadside Survey of Alcohol and Drug Use by Drivers." Traffic Safety Facts Research Note. National Highway Traffic Safety Administration, U.S. Department of Transportation. Washington, D.C. DOT HS 812118 , 2015.

Blattenberger, G., R. Fowles, and P.D. Loeb. "Determinants of Motor Vehicle Crash Fatalities Using Bayesian Model Selection Methods." Research in Transportation Economics 43, (2013): 112-122.

Callaghan, R.C., J.M. Gatley, S. Veldhuizen, S. Lev-Ran, R. Mann, and M. Asbridge. "Alcohol- or Drug-Use Disorders and Motor Vehicle Accident Mortality: A Retrospective Cohort Study." Accident Analysis and Prevention 53, (2013): 149-155.

DuPont, R.L. "Drugged Driving Research: A White Paper." National Institute on Drug Abuse. Bethesda, MD, 2011.

Federal Communications Commission. Table B-2 (FCC's Semi-Annual Local Telephone Competition Data Collection: Mobile Telephone Subscribership, 2008-2011). "Annual Report and Analysis of Competitive Market Conditions with Respect to Mobile Wireless, Including Commercial Mobile Services," 2013. https://apps.fcc.gov/edocs_public/attachmatch/FCC-13-34A1.pdf (accessed June 2015).

Garbacz, C. "Estimating Seat Belt Effectiveness with Seat Belt Usage Data from the Centers for Disease Control," Economic Letters 34(1), (1990): 83-88.

Gujarati, D.N. and D.C. Porter. Basic Econometrics. Fifth Edition. McGraw-Hill/Irwin, New York, NY, 2009.

Kelly-Baker, T., J.H. Lacey, A. Berning, A. Ramirez, C. Moore, K. Brainard, J. Yao, A.S. Tippetts, E. Romano, K. Carr, and K. Pell. "2013-2014 National Roadside Study of Alcohol and Drug Use by Drivers: Methodology." National Highway Traffic Safety Administration, U.S. Department of Transportation. Washington, D.C. DOT HS 812 294, 2016.

Lacey, J.H., T. Kelley-Baker, A. Berning, E. Romano, A. Ramirez, J. Yao, C. Moore, K. Brainard, K. Carr, K. Pell, and R. Compton. "Drug and Alcohol Crash Risk: A Case-Control Study." National Highway Traffic Safety Administration, U.S. Department of Transportation. Washington, D.C. DOT HS 812 355. 2016.

Lacey, J.H., T. Kelley-Baker, D. Furr-Holden, R.B. Voas, E. Romano, A. Ramirez, K. Brainard, C. Moore, P. Torres, and A. Berning. "2007 National Roadside Survey of Alcohol and Drug Use by Drivers: Drug Results." National Highway Traffic Safety Administration, U.S. Department of Transportation. Washington, D.C. DOT HS 811 249, 2009.

Li, G., J.E. Brady, and Q. Chen. "Drug Use and Fatal Motor Vehicle Crashes: A Case-Control Study." Accident Analysis and Prevention 60, (2013): 205-210.

Loeb, P.D., W.A. Clarke, and R. Anderson. "The Impact of Cell Phones on Motor Vehicle Fatalities." Applied Economics 41, (2009): 2905-2914.

Loeb, P.D., W.K. Talley, and T.J. Zlatoper. Causes and Deterrents of Transportation Accidents: An Analysis by Mode. Quorum Books, Westport, CT, 1994. 
National Center for Statistics and Analysis. "Lives Saved in 2014 by Restraint Use and MinimumDrinking-Age Laws." Traffic Safety Facts Crash Stats. National Highway Traffic Safety Administration, U.S. Department of Transportation. Washington, D.C. DOT HS 812 218, 2015.

National Institute on Alcohol Abuse and Alcoholism, National Institutes of Health. Table 3, "Per Capita Ethanol Consumption for States, Census Regions, and the United States, 1977-2009," 2011. http://pubs.niaaa.nih.gov/publications/Surveillance92/CONS09.htm (accessed January 2014).

National Institute on Alcohol Abuse and Alcoholism, National Institutes of Health. Table 3, "Per Capita Ethanol Consumption for States, Census Regions, and the United States, 1977-2012," 2014. http://pubs.niaaa.nih.gov/publications/surveillance98/CONS12.htm (accessed July 2014).

National Institute on Drug Abuse. "Drugged Driving.” Drug Facts, December 2014.

Ohio Insurance Institute. Speed Limit Laws, 2015. https://www.ohioinsurance.org/speed-limitlaws/ (accessed March 2015).

Peltzman, S. "The Effects of Automobile Safety Regulation." Journal of Political Economy 83(4), (1975): 677-725.

ProCon.org. "Medical Marijuana: Pros and Cons," 2015. http://medicalmarijuana.procon.org/view. resource.php?resourceID $=000881$ (accessed in January 2015).

Romano, E., P. Torres-Saavedra, R.B. Voas, and J.H. Lacey. "Drugs and Alcohol: Their Relative Crash Risk." Journal of Studies on Alcohol and Drugs 75(1), (2014): 56-64.

Rudisill, T.M., S. Zhao, M.A. Abate, J.H. Coben, and M. Zhu. "Trends in Drug Use Among Drivers Killed in U.S. Traffic Crashes.” Accident Analysis and Prevention 70, (2014): 178-187.

Substance Abuse and Mental Health Services Administration. State Estimates of Substance Use and Mental Disorders from the 2009-2010 National Surveys on Drug Use and Health, NSDUH Series H-43, HHS Publication No. (SMA) 12-4703. Rockville, MD, 2012.

U.S. Census Bureau. "Annual Estimates of the Resident Population for the United States, Regions, States, and Puerto Rico: April 1, 2000, to July 1, 2009 (NST-EST2009-01)," 2011. http://www. census.gov/popest/data/historical/2000s/vintage_2009/index.html (accessed June 2011).

U.S. Census Bureau. "2010 Census,” 2014. http://www.census.gov/2010census/ (accessed July 2014).

U.S. Department of Commerce, Bureau of Economic Analysis.

“SA51-53 Disposable Personal Income Summary,” 2011. http://www.bea.gov/iTable/iTable.cfm?re qid=70\&step=1\&isuri $=1 \&$ acrdn=4\#reqid=70\&step=30\&isuri $=1 \& 7028=-1 \& 7040=-1 \& 7083=$ level $\mathrm{s} \& 7031=0 \& 7022=21 \& 7023=0 \& 7024=$ non-industry $\& 7025=0 \& 7026=01000 \& 7027$ $=2012 \& 7001=421 \& 7029=23 \& 7090=70 \& 7033=-1($ accessed June 2011).

U.S. Department of Commerce, National Climate Data Center. “Climate at a Glance,” 2011. http:// lwf.ncdc.noaa.gov/oa/climate/research/cag3/cag3.html (accessed June 2011).

U.S. Department of Labor, Bureau of Labor Statistics. "Consumer Price Index - All Urban Consumers," 2014. http://www.bls.gov/ (accessed July 2014). 
U.S. Department of Transportation, Federal Highway Administration. (various years): Highway Statistics Series. http://www.fhwa.dot.gov/policy/ohpi/hss/hspubs.cfm (accessed June 2011 for 2009 data; accessed July 2014 for 2010 data).

U.S. Department of Transportation, National Highway Traffic Safety Administration. "Drug Involvement of Fatally Injured Drivers." DOT HS 811 415, 2010a. http://www-nrd.nhtsa.dot.gov/ Pubs/811415.pdf (accessed February 2015).

U.S. Department of Transportation, National Highway Traffic Safety Administration. "Fifth/Sixth Report to Congress: Effectiveness of Occupant Protection Systems and Their Use." DOT HS 809 442, 2001. http://www-nrd.nhtsa.dot.gov/Pubs/809-442.pdf (accessed March 2014)

U.S. Department of Transportation, National Highway Traffic Safety Administration. "Seat Belt Use in 2009-Use Rates in the States and Territories," Traffic Safety Facts. DOT HS 811 324, 2010 b. http://www-nrd.nhtsa.dot.gov/Pubs/811324.pdf (accessed June 2011).

U.S. Department of Transportation, National Highway Traffic Safety Administration. "Seat Belt Use in 2010-Use Rates in the States and Territories," Traffic Safety Facts. DOT HS 811 493, 2011. http://www-nrd.nhtsa.dot.gov/Pubs/811493.pdf (accessed July 2014).

Andrew Welki received his BA degree in economics from Wilkes College and his Ph.D. in economics from Penn State University. He started his John Carroll University career in 1982. Since then he has been a four-time recipient of the Wasmer Award for outstanding teaching in the Boler School of Business. In 2005 he received John Carroll's Distinguished Faculty Award. His research interests include sports economics and transportation safety issues, both domestically and internationally. He has published articles in a number of professional journals including the Atlantic Economic Journal, Managerial and Decision Economics, and the Journal of the Transportation Research Forum. His service as the faculty athletic representative to the NCAA and the Ohio Athletic Conference now exceeds 20 years. Welki is an avid sports fan and regularly attends a wide range of sporting events for men and women.

Tom Zlatoper is a professor of economics in the Department of Economics and Finance at John Carroll University. He received his B.A. in mathematics and economics from Boston College and his M.A. and Ph.D. in economics from Northwestern University. His research interests include transportation safety and sports economics. His work has been published in various scholarly journals including Journal of Transport Economics and Policy, Managerial and Decision Economics, and Transportation Research Part E; and he co-authored the book Causes and Deterrents of Transportation Accidents: An Analysis by Mode. 